\title{
Energy production from L-malic acid degradation and protection against acidic external pH in Lactobacillus plantarum CECT 220
}

\author{
María José García, ${ }^{1 *}$ ManUel ZÚÑIga ${ }^{1}$ and Hiroshi Kobayashi ${ }^{2}$ \\ ${ }^{1}$ Departamento de Microbiología, Facultad de Ciencias Biológicas, Universidad de Valencia, Spain \\ ${ }^{2}$ Department of Clinical Biochemistry, Faculty of Pharmaceutical Sciences, University of Chiba, Chiba 260, Japan
}

(Received 9 March 1992; revised 14 August 1992; accepted 20 August 1992)

\begin{abstract}
Malate degradation by Lactobacillus plantarum CECT 220 provides energy which enables this organism to remain viable for longer at low environmental pH values. Energy production was not coupled to $\mathrm{H}^{+}$-ATPase activity. This protective mechanism against acidic external $\mathrm{pH}$ is complemented by another system of $\Delta \mathrm{pH}$ maintenance. The $\mathrm{H}^{+}$-ATPase did not seem to be involved in this system of $\mathrm{pH}$ maintenance as the system was not sensitive to $N, N^{\prime}$ dicyclohexylcarbodiimide (DCCD) and was functional at very low pH values where ATPase activity was severely inhibited.
\end{abstract}

\section{Introduction}

Lactic acid bacteria (LAB) are obligate fermentative micro-organisms. As they produce large amounts of acid, tolerance to acidic environments is a valuable asset for their survival. This tolerance is particularly advantageous in vegetable fermentations and winemaking where LAB play an important role (Stamer, 1979).

The adaptation of these micro-organisms to low $\mathrm{pH}$ implies the development of protective mechanisms such as the arginine deiminase system proposed by Marquis et al. (1987). A similar role has been proposed for malolactic fermentation (MLF) (Kunkee, 1967; Caspritz \& Radler, 1983). MLF is the decarboxylation of L-malic acid to L-lactic acid by the malo-lactic enzyme (MLase), which is only found in LAB. This reaction does not seem to provide energy to the cells (Kunkee, 1967; Daeschel, 1988) but appears to be beneficial, because their growth rates are increased when grown in a medium with Lmalic acid and a carbon source (Pilone \& Kunkee, 1976). Recently, Cox \& Henick-Kling (1989) proposed a chemiosmotic hypothesis for MLF in Leuconostoc oenos where energy is produced by the efflux of L-lactate from L-malate degradation. It has also been shown that other LAB, including Lactobacillus plantarum, can obtain energy from L-malic acid degradation (Cox \& HenickKling, 1990).

\footnotetext{
* Author for correspondence. Tel. 3463864390.
}

Abbreviations: LAB, lactic acid bacteria; MLF, malo-lactic fermentation; MLase, malo-lactic enzyme; PCA, perchloric acid.
L. plantarum is one of the most widespread LAB. It has been isolated from dairy products, meat and meat products, silage, sugar processing, fruit juices, and man and other animals. Furthermore, it is commonly used in vegetable fermentations and winemaking as a starter culture (Prahl et al., 1988). The MLase of $L$. plantarum has been purified (Schütz \& Radler, 1973). As no malic enzyme activity has been detected in $L$. plantarum (Caspritz \& Radler, 1983; Battermann \& Radler, 1991), pyruvic acid production from L-malic acid, which could be diverted to energy generation, is not expected.

The aim of this work was to determine the role of MLF at low $\mathrm{pH}$ values and to investigate whether malo-lactic degradation could provide energy for $L$. plantarum. The results show several novel aspects of this process.

\section{Methods}

Organisms and growth media. L. plantarum CECT 220 was from the Colección Española de Cultivos Tipo (CECT, Universidad de Valencia, Spain). Cultures were maintained by weekly transfers in de Man, Rogosa, and Sharpe medium (MRS) (Oxoid) (de Man et al., 1960) supplemented with $0 \cdot 3 \%$ agar. For longer conservation the cultures were lyophilized. $L$. plantarum CECT 220 was grown routinely in MRS broth at $30^{\circ} \mathrm{C}$ in static culture. MRS agar plates were prepared by supplementing broth with $2 \%(w / v)$ agar.

Determination of minimum $\mathrm{pH}$ values for glucose metabolism and growth. Determination of minimum $\mathrm{pH}$ value for glucose metabolism was carried out as described by Casiano-Colón \& Marquis (1988). Cells were harvested in early stationary phase, centrifuged, washed twice in $20 \mathrm{~mm}$-potassium phosphate buffer, pH 5.5, containing $1 \mathrm{mM}-\mathrm{MgCl}_{2}$, and suspended ( $2 \mathrm{mg}$ dry weight $\mathrm{ml}^{-1}$ ) in the same buffer. Glucose was added to a final concentration of $20 \mathrm{~g} \mathrm{l}^{-1}$ to give an excess. Since LAB 
are obligate fermenters, the metabolism of glucose leads to a decrease of the medium $\mathrm{pH}$. External $\mathrm{pH}$ values were measured with an Orion (SA 520) $\mathrm{pH}$ meter. When $\mathrm{pH}$ readings were stable, the $\mathrm{pH}$ of the medium was increased to the initial $\mathrm{pH}$ value with sterile $1 \mathrm{M}-\mathrm{KOH}$ and $\mathrm{pH}$ measurements continued. A further decrease in $\mathrm{pH}$ indicated that the minimum $\mathrm{pH}$ for glucose metabolism had been reached. The minimum $\mathrm{pH}$ value for growth was obtained by culturing $L$. plantarum CECT 220 in MRS broth at $30^{\circ} \mathrm{C}$ at different initial $\mathrm{pH}$ values. Growth was monitored as $\mathrm{OD}_{600}$ with a Beckman DU-7 spectrophotometer.

Culture viability with and without L-malic acid at different $\mathrm{pH}$ values, and determination of minimum $\mathrm{pH}$ value for degradation of $L$-malic acid. Cells were harvested as described above, washed twice with $20 \mathrm{~mm}$ potassium phosphate buffer containing $1 \mathrm{mM}-\mathrm{MgCl}_{2}$ at the desired $\mathrm{pH}$ value and suspended in the same buffer with or without $5 \mathrm{~g}^{-1} \mathrm{~L}-\mathrm{malic}$ acid to obtain dense suspensions containing about $10^{9}$ c.f.u. $\mathrm{ml}^{-1}$. Incubation was carried out at $30^{\circ} \mathrm{C}$. The $\mathrm{pH}$ values used were 3.0 and 5.5. Samples were taken periodically and plated on MRS agar at pH 6.0. Plates were incubated at $30^{\circ} \mathrm{C}$ for $48 \mathrm{~h}$ before counting.

Quantification of organic acids concentration. Degradation of L-malate was followed by the UV method for determination of residual L-malic acid (Boehringer Mannheim, Barcelona). L-Lactic acid, D-lactic acid, and acetic acid were also measured similarly. Changes in external pH values were monitored simultaneously.

Measurements of $\Delta p H . \Delta \mathrm{pH}\left(=\mathrm{pH}_{\mathrm{i}}-\mathrm{pH}_{\mathrm{o}}\right.$, where $\mathrm{pH}_{\mathrm{i}}$ is the internal $\mathrm{pH}$ and $\mathrm{pH}_{\mathrm{o}}$ is the external $\mathrm{pH}$ ) was measured from the distribution of $\left[{ }^{14} \mathrm{C}\right]$ salicylic acid $\left(10 \mu \mathrm{M}, 0.05 \mathrm{nCi} \mu l^{-1}, 1.85 \mathrm{~Bq}_{\mu l^{-1}}\right)$ as described (Kobayashi et al., 1982) with modifications. To calculate $\mathrm{pH}_{\mathrm{i}}$, the data were corrected since the $\mathrm{pH}_{\mathrm{o}}$ was lower than the $\mathrm{p} K_{\mathrm{a}}+1$ of the radiolabelled marker (Rottenberg, 1979). This means that a significant part of the marker is not dissociated, so $\mathrm{pH}_{\mathrm{i}}$ was calculated from:

$$
\mathrm{pH}_{\mathrm{i}}=\log \left[\left([\mathrm{A}]_{\mathrm{i}} /[\mathrm{A}]_{\mathrm{o}}\right)\left(10^{\mathrm{p} \mathrm{K}_{\mathrm{a}}}+10^{\mathrm{ph} \mathrm{H}_{\mathrm{o}}}\right)-10^{\mathrm{p} K_{\mathrm{s}}}\right]
$$

where $[A]_{i}$, and $[A]_{o}$ are the internal and external concentration of radiolabelled marker (dissociated and not dissociated) respectively.

Cells were suspended in $20 \mathrm{~mm}$-potassium phosphate buffer ( $\mathrm{pH} 3.0$ or 5.5) containing $1 \mathrm{~mm}-\mathrm{MgCl}_{2} \cdot\left[{ }^{14} \mathrm{C}\right]$ salicylic acid was added and the suspension was incubated at $30^{\circ} \mathrm{C}$ for at least $10 \mathrm{~min}$. Samples $(50 \mu \mathrm{l})$ were analysed by scintillation spectroscopy (Packard 3255) in vials containing Bray's solution. The remaining part of the suspension was filtered through a glass microfibre filter (Whatman $G F / F$ ) and the radioactivity on the filter determined. Replacement of $\left[{ }^{14} \mathrm{C}\right]$ salicylic acid by $\left[{ }^{14} \mathrm{C}\right]$ benzoic acid did not affect the results obtained (data not shown). As a positive control, $1 \%(w / v)$ glucose was added to the cell suspension, and incubated for $10 \mathrm{~min}$. Small $\Delta \mathrm{pH}$ were corrected by subtracting the $\triangle \mathrm{pH}$ values obtained in the presence of gramicidin D $\left(4 \mu \mathrm{g} \mathrm{ml}^{-1}\right) . N, N^{\prime}$-Dicyclohexylcarbodiimide (DCCD) was added (final concentration, $0.2 \mathrm{mM}$ ) to inhibit ATPase activity. Carbonylcyanide $m$ chlorophenylhydrazone (CCCP) was used at a final concentration of $20 \mu \mathrm{M}$. Ionophores and uncouplers used were allowed to act for $20 \mathrm{~min}$ before measurements of $\Delta \mathrm{pH}$. The internal volume of $3.2 \mu \mathrm{l}(\mathrm{mg}$ protein $)^{-1}$ of $L$. plantarum CECT 220 was determined as described (Rottenberg, 1979).

Everted membrane vesicles. Membrane vesicles were obtained as described (Russell et al., 1988) except that the vesicles were

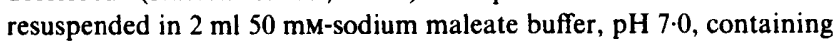
$10 \mathrm{mM}^{-\mathrm{MgSO}_{4}}$ (final protein concentration $9.4 \mathrm{mg}$ protein $\mathrm{ml}^{-1}$ ). Everted membrane vesicles were obtained by passing the final suspension through a French pressure cell at $703 \mathrm{~kg} \mathrm{~cm}^{-2}$ (Aminco) and stored at $-80^{\circ} \mathrm{C}$ until use.

Assay of ATPase activity and measurements of intracellular ATP. Measurements of ATPase activity were performed by determining $P_{i}$ released from ATP (Kobayashi \& Anraku, 1972). The procedure was carried out using everted membrane vesicles as a source of ATPase activity.

ATP concentrations in cell extracts were measured using the luciferin-luciferase method (Lundin \& Thore, 1975) with a 1234-102 ATP Monitoring Kit (LKB Wallac, Barcelona) and a LKB Wallac 1250 luminometer. Cells were grown in MRS broth at $30^{\circ} \mathrm{C}$ until early stationary phase, harvested by centrifugation $\left(15300 \mathrm{~g}, 20 \mathrm{~min}, 4^{\circ} \mathrm{C}\right)$ and suspended in $20 \mathrm{~mm}$-potassium phosphate buffer containing $1 \mathrm{~mm}$ $\mathrm{MgCl}_{2}$ ( $\mathrm{pH} \mathrm{3.0}$ or 5.5 ) to a concentration of $3-4 \mathrm{mg}$ protein $\mathrm{ml}^{-1}$. Samples $(4 \mathrm{ml})$ were taken after $24 \mathrm{~h}$ incubation at $30^{\circ} \mathrm{C}$ in the buffer, and combinations of $\mathrm{L}$-malic acid $\left(5 \mathrm{~g} \mathrm{l}^{-1}\right), \operatorname{DCCD}(0 \cdot 2 \mathrm{mM})$, glucose $(1 \% \mathrm{w} / \mathrm{v})$, and gramicidin $\mathrm{D}\left(4 \mu \mathrm{g} \mathrm{ml}^{-1}\right)$ added. Cells were incubated for $10 \mathrm{~min}$ at $30^{\circ} \mathrm{C}$ after addition of the compounds. None of the treatments altered the $\mathrm{pH}_{\mathrm{o}}$. One $\mathrm{ml}$ of treated cells was extracted as described (Strobel \& Russell, 1989) with $0.5 \mathrm{ml}$ cold $14 \%$ (v/v) PCA containing $9 \mathrm{~mm}$-EDTA for $20 \mathrm{~min}$ on ice. Cell debris was removed by centrifugation $\left(13000 \mathrm{~g}, 5 \mathrm{~min}, 4^{\circ} \mathrm{C}\right)$. One $\mathrm{ml}$ of supernatant was neutralized with $0.5 \mathrm{ml} \mathrm{KOH} / \mathrm{KHCO}_{3}$. Precipitates were removed by centrifugation $\left(13000 \mathrm{~g}, 5 \mathrm{~min}, 4^{\circ} \mathrm{C}\right)$, and the supernatants stored at $-20^{\circ} \mathrm{C}$ until use.

Protein determination. The amount of protein was determined by the method of Lowry using bovine serum albumin as standard.

All measurements were performed at least in duplicate. The results given are the average.

\section{Results}

\section{Growth, cell viability, and L-malate degradation by L. plantarum}

Non-growing cells of $L$. plantarum CECT 220 degraded glucose until the external $\mathrm{pH}$ reached $2 \cdot 7$, whereas Lmalic acid could be degraded down to external pH $2 \cdot 4$. In MRS broth, cell growth stopped at $\mathrm{pH} 3 \cdot 1$, but glucose continued to be degraded until pH 2.95 was reached. The minimum $\mathrm{pH}$ values for glucose degradation obtained with non-growing and growing cells are not similar, because acid tolerance changes depending on the environmental conditions (Casiano-Colón \& Marquis, 1988).

Cells remained viable longer in the presence of $L$-malic acid in buffers at either $\mathrm{pH} 3.0$ or 5.5 (Fig. 1 a). L-Malic acid degradation activity was observed at $\mathrm{pH} 3.0$. At an initial $\mathrm{pH}$ of 5.5 , however, $\mathrm{L}$-malic acid was not completely depleted; approximately $1 \mathrm{~g} \mathrm{l}^{-1}$ remained after $220 \mathrm{~h}$ of incubation (Fig. $1 b$ ). The cell viability at both $\mathrm{pH} 3.0$ and 5.5 remained almost unchanged until malic acid degradation stopped, after which viability decreased, but not as rapidly as in the absence of malate (Fig. $1 a, b)$. Degradation of $\mathrm{L}$-malic acid was accompanied by an increase in external $\mathrm{pH}$, as expected. The external $\mathrm{pH}$ values rose from 3.0 to 3.4 , and from 5.5 to 7.5 after $120 \mathrm{~h}$ of incubation. Despite the more

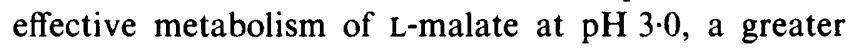
increase of external $\mathrm{pH}$ was detected at $\mathrm{pH} 5 \cdot 5$. Although a slight increase of external $\mathrm{pH}$ at initial $\mathrm{pH} 3.0$ occurred 

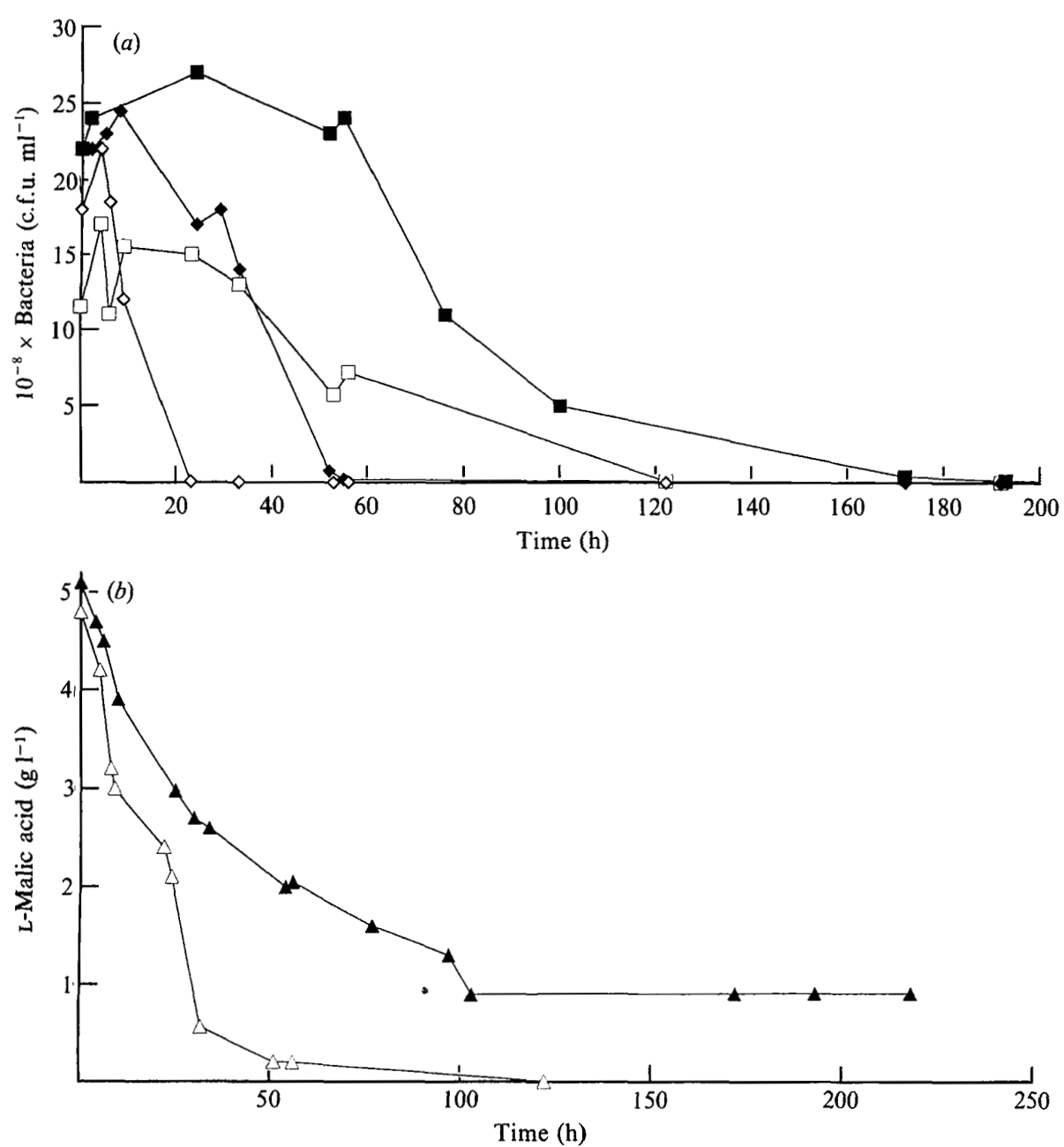

Fig. 1. Viability $(a)$ and degradation of $\mathrm{L}-\mathrm{malic}$ acid $(b)$ as a function of time at initial external $\mathrm{pH}$ values $3 \cdot 0$ and $5 \cdot 5$, by $L$. plantarum CECT 220 cells suspended in $20 \mathrm{~mm}$ potassium phosphate buffer containing $1 \mathrm{mM}-\mathrm{MgCl}_{2}$. $\mathbf{D}$, L-malic acid added, $\mathrm{pH} 5 \cdot 5 ; \bullet$, no L-malic acid added, pH 5.5; $\square$, L-malic acid added, pH 3.0; $\diamond$, no L-malic acid added, pH 3.0; $\Delta, \mathrm{pH} 5.5 ; \triangle, \mathrm{pH} 3.0$.

(only 0.4 units), the cells remained viable longer in presence of L-malic acid.

The main products of L-malic acid degradation by $L$. plantarum CECT 220 at pH 5.5 were L-and D-lactic acids (Fig. 2). Minor amounts of acetic acid were also produced (Fig. 2). Similar results were obtained when cells were incubated at pH 3.0 (data not shown). $\mathrm{CO}_{2}$ production was not measured in these experiments. It is generally accepted that MLF yields only L-lactic acid and $\mathrm{CO}_{2}$ but our results do not bear this out. This discrepancy is discussed later.

Generation of a $\triangle p H$ in non-growing cells at $p H 3.0$ and 5.5 with or without L-malate

Starvation of cells (incubation without L-malic acid) resulted in a very rapid decrease in the $\Delta \mathrm{pH}$ and viability. High $\Delta \mathrm{pHs}$ were generated at $\mathrm{pH} 3.0$ when cells were incubated with L-malic acid (Table 2 ), whereas a low $\Delta \mathrm{pH}$ was detected at $\mathrm{pH} 5 \cdot 5$. This could be due to the lower L-malic acid degradation rate at $\mathrm{pH} 5.5$ (Fig. $1 b$ ). Cells were incubated in buffer at $\mathrm{pH} 3.0$ in the presence or absence of $5 \mathrm{~g}$ of L-malic acid $\mathrm{I}^{-1}$ for $6 \mathrm{~h}$. Gramicidin D and CCCP dissipated the $\triangle \mathrm{pH}$ (Table 2), which suggested that circulation of protons takes place upon addition of L-malic acid. Nevertheless, since the dissipation by ionophores was not complete, a Donnan potential may contribute partially to generation of $\Delta \mathrm{pH}$ at low $\mathrm{pH}$. When cells were treated with DCCD at pH 5.5 , the $\Delta \mathrm{pH}$ was completely dissipated, both in the presence of malate (in which case the external $\mathrm{pH}$ reached a value of 5.9 due to malate degradation) and glucose (Table 1). These results indicated that $\mathrm{H}^{+}$ ATPase was involved in maintaining the $\Delta \mathrm{pH}$ at $\mathrm{pH} 5 \cdot 5$. In contrast, cells treated with $\mathrm{DCCD}$ at $\mathrm{pH} 3.0$ were able 


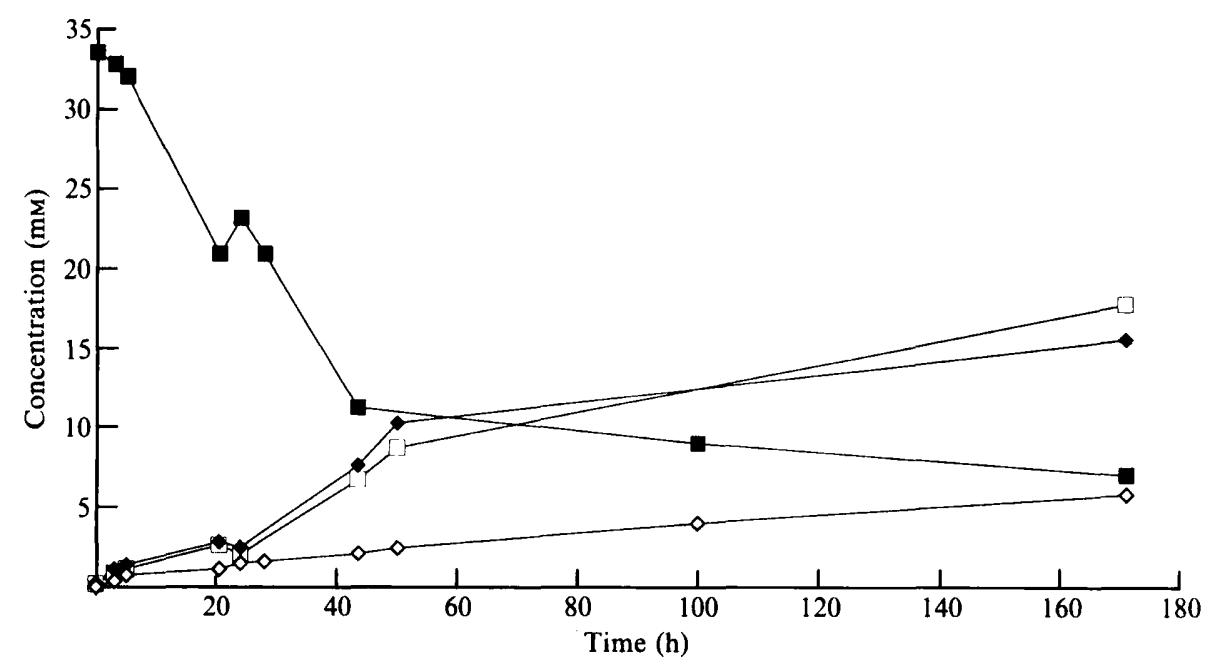

Fig. 2. Degradation of L-malic acid and production of L-lactic acid, D-lactic acid, and acetic acid by non-growing cells suspended in potassium phosphate buffer at an external pH of 5.5. $\square$, L-malic acid; $\diamond$, L-lactic acid; $\square$, D-lactic acid; $\diamond$, Acetic acid.

Table 1. Intracellular ATP of cells suspended in $20 \mathrm{mM}$ potassium phosphate buffer at external $\mathrm{pH}$ values of 3.0 or 5.5 after $24 \mathrm{~h}$ incubation at $30^{\circ} \mathrm{C}$

\begin{tabular}{lcc}
\hline \hline & \multicolumn{2}{c}{ pmol ATP (mg protein) $)^{-1}$} \\
\cline { 2 - 3 } Treatment & $\mathrm{pH}_{\mathrm{o}} 3 \cdot 0$ & $\mathrm{pH}_{\mathrm{o}} 5 \cdot 5$ \\
\hline Untreated cells & 46 & 43 \\
L-Malic acid & 210 & 200 \\
DCCD + L-malic acid & 260 & 220 \\
Glucose & 440 & 170 \\
DCCD + glucose & 500 & 250 \\
L-Malic acid + gramicidin D & 9 & 0 \\
\hline \hline
\end{tabular}

to maintain the $\Delta \mathrm{pH}$ in the presence of glucose and Lmalate (Table 2). In this context it is possible that DCCD was somehow unable to inhibit ATPase at $\mathrm{pH} 3.0$. However, ATPase activity in everted membrane vesicles was sensitive to DCCD at both pH 3.0 and 5.5 (data not shown).

ATP was produced upon addition of L-malic acid at both $\mathrm{pH} 3.0$ and 5.5 (Table 1). ATP was produced from malate degradation even if cells were treated with DCCD. This suggests that L-malate degradation provides energy in a way that does not involve ATPase activity.

Table 2. Measurement of $\triangle p H$ in L. plantarum CECT 220 cells incubated in $20 \mathrm{mM}$ potassium phosphate buffer at initial external pH values of 3.0 or 5.5

\begin{tabular}{|c|c|c|c|c|c|}
\hline \multirow{2}{*}{$\begin{array}{l}\text { Incubation } \\
\text { time (h) }\end{array}$} & \multirow[b]{2}{*}{ Treatment } & \multicolumn{2}{|c|}{$\mathrm{pH}_{\mathrm{o}} 3.0$} & \multicolumn{2}{|c|}{$\mathrm{pH}_{\mathrm{o}} 5 \cdot 5$} \\
\hline & & $\mathrm{pH}_{\mathrm{o}}$ & $\Delta \mathrm{pH}$ & $\mathrm{pH}_{\mathrm{o}}$ & $\Delta \mathrm{pH}$ \\
\hline 0 & None & $3 \cdot 0$ & 1.6 & $5 \cdot 5$ & 0.4 \\
\hline 0 & L-Malic acid & 3.0 & $2 \cdot 2$ & $5 \cdot 5$ & 0.5 \\
\hline 0 & Glucose & $3 \cdot 0$ & $2 \cdot 4$ & $5 \cdot 5$ & 1.8 \\
\hline 6 & None & 3.0 & $1 \cdot 2$ & $5 \cdot 1$ & No $\Delta \mathrm{pH}$ \\
\hline 6 & L-Malic acid & $3 \cdot 1$ & 1.8 & $5 \cdot 9$ & No $\Delta \mathrm{pH}$ \\
\hline 6 & L-Malic acid + DCCD & $3 \cdot 1$ & 1.7 & 5.9 & No $\Delta \mathrm{pH}$ \\
\hline 6 & L-Malic acid + CCCP & $3 \cdot 1$ & $1 \cdot 1$ & ND & ND \\
\hline 6 & L-Malic acid + gramicidin D & $3 \cdot 1$ & 0.7 & ND & ND \\
\hline 6 & Glucose & 3.0 & $2 \cdot 4$ & $5 \cdot 1$ & 1.7 \\
\hline 6 & Glucose + DCCD & 3.0 & $2 \cdot 4$ & $5 \cdot 1$ & No $\Delta \mathrm{pH}$ \\
\hline
\end{tabular}

$\mathrm{ND}$, not determined. 


\section{Discussion}

The MLase activity of whole cells suspended in buffer was higher at $\mathrm{pH} 3.0$ than at $\mathrm{pH} 5.5$ (Fig. 1 b); similar to the results of Henick-Kling (1986). However, the optimum $\mathrm{pH}$ for MLase activity of the purified enzyme is around 5.5-6.0, (Kandler et al., 1973; Strasser de Saad et al., 1984). Possible explanations are that malic acid permease has a lower optimum $\mathrm{pH}$ than malo-lactic enzyme, or that the regulatory system of malo-lactic process is $\mathrm{pH}$-dependent. The results showed that the minimum $\mathrm{pH}$ for MLF (pH 2.4) was lower than that for glycolysis ( $\mathrm{pH} 2 \cdot 7$ ), and growth ( $\mathrm{pH} \mathrm{3 \cdot 1)}$. Moreover, cells remained viable longer in buffer with L-malic acid (Fig. $1 a$ ), and MLF activity was higher at $\mathrm{pH} 3.0$ than at 5.5. These results indicate that MLF in L. plantarum CECT 220 is a protective system in acidic environments.

The proposed mechanism for MLF includes neither the formation of ATP nor the reduction of NAD (Kunkee, 1967). Kandler et al. (1973) suggested that the stimulatory effect on the growth of LAB by the MLF was due exclusively to the increase of the environmental $\mathrm{pH}$. This has also been suggested with the arginine deiminase system (Marquis et al., 1987; Casiano-Colón \& Marquis, 1988), but arginine degradation is accompanied by a high increase in external $\mathrm{pH}$ as $\mathrm{NH}_{3}$ is produced. We observed that incubation of cells in buffer at $\mathrm{pH} 3.0$ with L-malic acid only produced a slight increase of the external $\mathrm{pH}$, but this increase is insufficient to explain the higher viability obtained in the presence of $\mathrm{L}$-malic acid at $\mathrm{pH} 3.0$, since cells incubated at $\mathrm{pH} 5.5$ in buffer with no L-malic acid died faster than those incubated at pH 3.0 with L-malic acid (Fig. 2a). Conversely, our results show that $L$. plantarum CECT 220 can obtain energy from malic acid degradation even at low $\mathrm{pH}$ values. Significant levels of intracellular ATP were also detected upon addition of $\mathrm{L}$-malic acid to cells starved for $24 \mathrm{~h}$ (Table 1), which means that ATP production was not due to the degradation of storage products.

Cox \& Henick-Kling (1989) proposed that the L-lactic acid produced from the degradation of $L$-malic acid could be extruded in symport with protons to generate a membrane potential that would enable the membranebound $\mathrm{H}^{+}$-ATPase to produce ATP. This proposal was based on the observation that an electrochemical proton gradient is generated by lactate efflux (Otto et al., 1980). However, ATP production in L. plantarum CECT 220 can not be explained by a chemiosmotic mechanism as proposed by Cox \& Henick-Kling (1989), since ATP production was not affected by DCCD in cells incubated in buffer at $\mathrm{pH} 5.5$ (Table 1), where the ATPase was effectively inhibited.

To clarify the origin of this ATP production, the products from L-malate degradation by cells suspended in buffer were analysed. According to the mechanism generally accepted for MLF, no D-lactic acid production would be expected from malate degradation by MLase (Kunkee, 1967). However, we detected high levels of Dlactate (Fig. 2), which could be explained if L. plantarum CECT 220 possessed malic enzyme. Nevertheless, no malic enzyme activity has been detected in this species (Battermann \& Radler, 1991). The only LAB with malic enzyme are Enterococcus faecalis and L. casei, and L. casei is the only one in which both enzymes have been detected (Battermann \& Radler, 1991). Battermann \& Radler (1991) reported that in $L$. casei malic enzyme is unstable at $\mathrm{pH}$ values lower than 6.0 whereas the malo-lactic enzyme is stable at $\mathrm{pH} 4.0$. In this study the highest internal $\mathrm{pH}$ measured was $5 \cdot 2$, when the external $\mathrm{pH}$ was adjusted to $3 \cdot 0$, in the presence of $L$-malic acid. Thus, it seems unlikely that malic enzyme could account for Dlactic acid production from L-malic acid under these conditions. L. plantarum CECT 220 could possess racemases to convert part of the L-lactic acid produced from L-malic acid to D-lactic acid. These enzymes have been found in L. plantarum and L. brevis (Radler et al., 1970). ATP production could be coupled to the formation of acetic acid which could be derived from lactic acid. In L. plantarum, lactate can be further degraded to pyruvic acid and acetic acid (Murphy et al., 1985; Lindgren et al., 1990). The present study cannot exclude either of these proposals.

L. plantarum maintains a $\Delta \mathrm{pH}$ with malic acid at low $\mathrm{pH}$. The generation of $\Delta \mathrm{pH}$ is via the membrane-bound $\mathrm{H}^{+}$-ATPase in most LAB (Kobayashi et al., 1982; Kashket, 1987). When cells were treated with DCCD at pH 5.5, to inhibit $\mathrm{H}^{+}$-ATPase, the $\Delta \mathrm{pH}$ in the presence of either glucose or malic acid was dissipated as expected. This implied that $\mathrm{H}^{+}$-ATPase is involved in $\triangle \mathrm{pH}$ maintenance at $\mathrm{pH} 5 \cdot 5$. However, DCCD did not dissipate the $\triangle \mathrm{DpH}$ at $\mathrm{pH} 3.0$ when cells were incubated with L-malic acid or glucose (Table 2). ATPase activity was strongly inhibited by $\mathrm{pH}$ and the residual activity was inhibited by DCCD (data not shown). MLF increased the internal $\mathrm{pH}$ because one $\mathrm{H}^{+}$is consumed per molecule of L-malic acid degraded; thus, $\Delta \mathrm{pH}$ generation by this process would not be sensitive to DCCD. However, the generation of a $\triangle \mathrm{pH}$ by glucose at pH 3.0 does not produce less acidic products and the $\triangle \mathrm{pH}$ generation was not affected by DCCD. These results cannot be completely explained by the formation of a Donnan potential, although a Donnan potential probably accounted for $\Delta \mathrm{pH}$, as gramicidin $\mathrm{D}$ and CCCP did not dissipate completely the $\Delta \mathrm{pH}$ (Table 2).

Cox \& Henick-Kling (1989) hypothesized that the ATPase was responsible for the $\Delta \mathrm{pH}$ generation. However, Maloney (1990) postulated and Poolman et al. (1991) recently confirmed that a malate ${ }^{2-} /$ lactate $^{1-}$ 
antiport exchange would generate a membrane potential, while the decarboxylation reaction established the $\triangle \mathrm{pH}$. This system would be insensitive to DCCD as ATPase is not involved in the generation of the $\Delta \mathrm{pH}$. This cannot explain the results obtained with glucose and DCCD at pH 3.0. Nevertheless, LAB can divert the pyruvate produced from the homolactic fermentation of hexoses to the production of other compounds under stress conditions (e.g. low pH) (Rhee \& Pack, 1980). Recently, Tsau et al. (1992) reported that L. plantarum was able to accumulate pyruvate and, at low environmental $\mathrm{pH}$ values, shift to the production of acetoin (a neutral compound). In this way, a $\Delta \mathrm{pH}$ could be generated independently from ATPase activity.

In summary, MLF is a protective system against cell death at acidic environmental $\mathrm{pH}$ values. This system functions by the formation of a $\Delta \mathrm{pH}$, generating ATP. The $\Delta \mathrm{pH}$ is probably established by a malate ${ }^{2-} /$ lactate $^{1-}$ antiport exchange, with ATP production linked to the degradation of lactate to acetate.

This investigation was supported by a research grant from Comisión Interministerial para la Ciencia y la Tecnología (CICYT BIO89-0430). M. J. García was supported by a predoctoral fellowship from the Ministerio de Educación y Ciencia. We are very indebted to Dr C. Guerri for the use of the luminometer, and to F. J. Iborra, M. Campos and J. L. León for technical assistance.

\section{References}

BattermanN, G. \& Radler, F. (1991). A comparative study of malolactic enzyme and malic enzyme of different lactic acid bacteria. Canadian Journal of Microbiology 37, 211-217.

Casiano-Colón, A. \& Marquis, R. E. (1988). Role of the arginine deiminase system in protecting oral bacteria and an enzymatic basis for acid tolerance. Applied and Environmental Microbiology 54, 13181324.

CASPRITZ, G. \& RADLER, F. (1983). Malolactic enzyme of Lactobacillus plantarum. Purification, properties, and distribution among bacteria. Journal of Biological Chemistry 258, 4907-4910.

Cox, D. J. \& Henick-KLING, T. (1989). Chemiosmotic energy from malolactic fermentation. Journal of Bacteriology 171, 5750-5752.

Cox, D. J. \& Henick-KLING, T. (1990). A comparison of lactic acid bacteria for energy-yielding (ATP) malolactic enzyme systems. American Journal of Enology and Viticulture 41, 215-218.

DAESCHEL, M. A. (1988). A pH control system based on malate decarboxylation for the cultivation of lactic acid bacteria. Applied and Environmental Microbiology 54, 1627-1629.

HENICK-KLING, T. (1986). Growth and metabolism of Leuconostoc oenos and Lactobacillus plantarum in wine. PhD Thesis, University of Adelaide, Australia.

Kandler, O., Winter, J. \& Stetter, K. O. (1973). Zur Frage der Beeinflussung der Glucosevergärung durch L-Malat bei Leuconostoc mesenteroides. Archiv für Mikrobiologie 90, 65-75.

KASHKET, E. R. (1987). Bioenergetics of lactic acid bacteria: cytoplasmic $\mathrm{pH}$ and osmotolerance. FEMS Microbiology Reviews 46, 233-244.
Kobayashi, H. \& ANRaKU, Y. (1972). Membrane-bound adenosine triphosphatase of Escherichia coli. I. Partial purification and properties. Journal of Biochemistry 71, 387-399.

Kobayashi, H., Murakami, N. \& Unemoto, T. (1982). Regulation of the cytoplasmic pH in Streptococcus faecalis. Journal of Biological Chemistry 257, 13246-13252.

KUNKEE, R. E. (1967). Malo-lactic fermentation. Advances in Applied Microbiology 9, 235-279.

Lindgren, S. E., Axelsson, L. T. \& McFeeters, R. F. (1990). Anaerobic L-lactate degradation by Lactobacillus plantarum. FEMS Microbiology Letters 66, 209-213.

LUNDIN, A. \& THORE, A. (1975). Comparison of methods for extraction of bacterial adenine nucleotides determined by firefly assay. Applied and Environmental Microbiology 30, 713-721.

Maloney, P. C. (1990). Microbes and membrane biology. FEMS Microbiology Reviews 87, 91-102.

De Man, J. C., Rogosa, M. \& Sharpe, M. E. (1960). A medium for the cultivation of lactobacilli. Journal of Applied Bacteriology 23, 130135.

Marquis, R. E., Bender, G. R., Murray, D. R. \& Wong, A. (1987) Arginine deiminase system and bacterial adaptations to acid environments. Applied and Environmental Microbiology 53, 198-200.

Murphy, M. G., O'ConNor, L., Walsh, D. \& ConDon, S. (1985). Oxygen-dependent lactate utilization by Lactobacillus plantarum. Archives of Microbiology 141, 75-79.

Otto, R., Sonnenberg, S. M., Veldkamp, H. \& Konings, W. N. (1980). Generation of an electrochemical proton gradient in Streptococcus cremoris by lactate efflux. Proceedings of the National Academy of Sciences of the United States of America 77, 5502-5506.

PILONE, G. J. \& KUNKeE, R. E. (1976). Stimulatory effect of malo-lactic fermentation on the growth rate of Leuconostoc oenos. Applied and Environmental Microbiology 32, 405-408.

Poolman, B., Molenaar, D., Smid, E. J., Ubbink, T., Abee, T., Renault, P. P. \& Konings, W. N. (1991). Malolactic fermentation: electrogenic malate uptake and malate/lactate antiport generate metabolic energy. Journal of Bacteriology 173, 6030-6037.

Prahl, C., Lonvaud-Funel, A., Karsgaard, S., Morrison, E. \& JOYEUX, A. (1988). Étude d'un procédé de déclenchement de la fermentation malolactique. Connaissance de la Vigne et du Vin 22, 197-207.

Radler, F., SchüTz, M. \& Doelle, H. W. (1970). Die beim Abbau von L-Äpfelsäure durch Milchsäurebakterien entstehenden Isomeren der Milchsäure. Naturwissenschaften 57, 672-675.

RheE, S. K. \& PACK, M. Y. (1980). Effect of environmental pH on fermentation balance of Lactobacillus bulgaricus. Journal of Bacteriology 144, 217-221.

ROTTENBERG, H. (1979). The measurement of membrane potential and $\Delta \mathrm{pH}$ in cells, organelles, and vesicles. Methods in Enzymology 50, 547-569.

Russell, J. B., Strobel, H. J., Driessen, A. J. M. \& Konings, W. N. (1988). Sodium-dependent transport of neutral amino acids by whole cells and membrane vesicles of Streptococcus bovis, a ruminal bacterium. Journal of Bacteriology 170, 3531-3536.

SCHÜTZ, M. \& RADleR, F. (1973). Das 'Malatenzym' von Lactobacillus plantarum und Leuconostoc mesenteroides. Archiv für Mikrobiologie 91 , 183-202.

STAMER, J. R. (1979). The lactic acid bacteria: microbes of diversity. Food Technology 33, 60-65

Strasser de SaAd, A. M., Pesce de Ruiz Holgado, A. A. \& Oliver, G. (1984). Purification and properties of malolactic enzyme from Lactobacillus murinus CNRZ 313. Journal of Applied Biochemistry 6, 374-383.

Strobel, H. J. \& Russell, J. B. (1989). Non-proton-motive-forcedependent sodium efflux from the ruminal bacterium Streptococcus bovis: bound versus free pools. Applied and Environmental Microbio$\log y$ 55, 2664-2668.

Tsau, J.-L., Guffanti, A. A. \& Montville, T. J. (1992). Conversion of pyruvate to acetoin helps to maintain $\mathrm{pH}$ homeostasis in Lactobacillus plantarum. Applied and Environmental Microbiology 58, 891-894. 